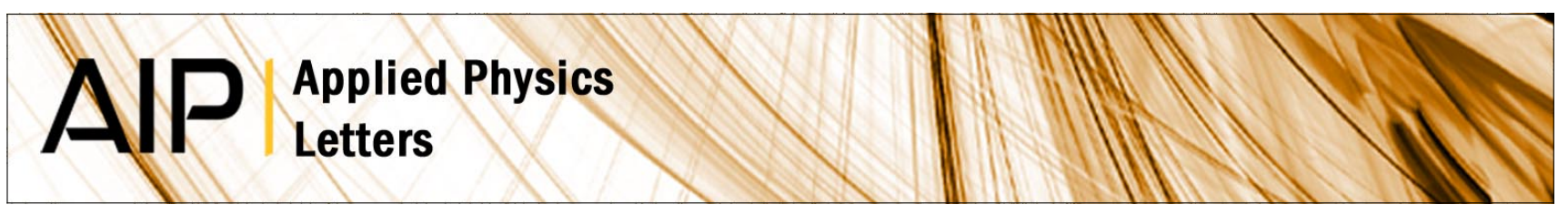

\title{
Effect of microalloying on the toughness of metallic glasses
}

Glenn R. Garrett, Marios D. Demetriou, Jason Chen, and William L. Johnson

Citation: Appl. Phys. Lett. 101, 241913 (2012); doi: 10.1063/1.4769997

View online: http://dx.doi.org/10.1063/1.4769997

View Table of Contents: http://apl.aip.org/resource/1/APPLAB/v101/i24

Published by the American Institute of Physics.

\section{Related Articles}

Charge trapping in [poly-(2-methoxyl),5-(3,77dimethyloctyloxy)] paraphenylenevinylene synthesized in different routes affected by the energetical distribution of trapping states

J. Appl. Phys. 113, 013104 (2013)

Simultaneous iron gettering and passivation of p-type monocrystalline silicon using a negatively charged aluminum-doped dielectric

Appl. Phys. Lett. 101, 252105 (2012)

Facile characterization of ripple domains on exfoliated graphene

Rev. Sci. Instrum. 83, 073905 (2012)

Improved memory characteristics by NH3-nitrided GdO as charge storage layer for nonvolatile memory applications

Appl. Phys. Lett. 101, 033501 (2012)

Mn-activated K2ZrF6 and Na2ZrF6 phosphors: Sharp red and oscillatory blue-green emissions J. Appl. Phys. 112, 013506 (2012)

\section{Additional information on Appl. Phys. Lett.}

Journal Homepage: http://apl.aip.org/

Journal Information: http://apl.aip.org/about/about_the_journal

Top downloads: http://apl.aip.org/features/most_downloaded

Information for Authors: http://apl.aip.org/authors

\section{ADVERTISEMENT}

\section{AIP Applied Physics Letters}

\section{EXPLORE WHAT'S NEW IN APL}

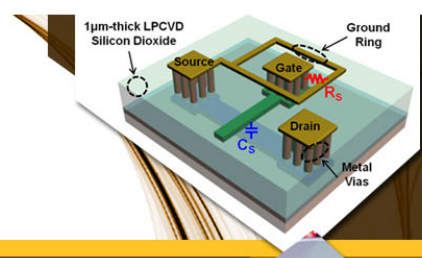

SURFACES AND INTERFACES

Focusing on physical, chemical, biological structural, optical, magnetic and electrical properties of surfaces and interfaces, and more.. 


\title{
Effect of microalloying on the toughness of metallic glasses
}

\author{
Glenn R. Garrett, ${ }^{\text {a) }}$ Marios D. Demetriou, Jason Chen, and William L. Johnson \\ Keck Engineering Laboratories, California Institute of Technology, Pasadena, California 91125, USA
}

(Received 13 August 2012; accepted 20 November 2012; published online 12 December 2012)

\begin{abstract}
The effect of microalloying on the toughness of $\mathrm{Cu}$-Ti-based metallic glasses is explored. Minor additions of $\mathrm{Si}$ and $\mathrm{Sn}$ in glass former $\mathrm{Cu}_{47} \mathrm{Ti}_{34} \mathrm{Zr}_{11} \mathrm{Ni}_{8}$ known to improve glass-forming ability are found here to sharply decrease toughness. The drop in toughness is associated with a small but meaningful increase in shear modulus, glass-transition temperature, yield strength, and a decrease in Poisson's ratio, implying a negative correlation between toughness and shear flow barrier. The strong influence of minor additions on the glass properties could be a useful tool for simultaneously tuning both the glass-forming ability and toughness of metallic glasses. (C) 2012 American Institute of Physics. [http://dx.doi.org/10.1063/1.4769997]
\end{abstract}

The addition of minority elements, or microalloying, has a long history in metallurgical applications and is well practiced in the field of metallic glass research. ${ }^{1}$ Minor additions are used to increase strength, thermal stability, glass-forming ability (GFA), corrosion resistance, magnetic properties, and plasticity. ${ }^{2}$ Dramatic changes in properties can be achieved with additions of $1 \%-2 \%$, but significant changes are not uncommon with additions of less than $1 \%{ }^{3,4}$ Such minute changes in alloy composition are not enough to change the chemistry or electronic structure of the glass-forming liquid but leads to a dramatic change in global properties nonetheless. Recent work suggests that these large changes from minor additions occur because of an alteration in the medium range order of the liquid that affects the elastic stress distribution. ${ }^{5}$ In the present study, we investigate the effects of microalloying on the toughness of metallic glass and the glass properties that influence fracture resistance.

The GFA of $\mathrm{Cu}_{47} \mathrm{Ti}_{34} \mathrm{Zr}_{11} \mathrm{Ni}_{8}$, first reported by Lin et al. ${ }^{6}$ as a marginal glass former, has been improved through various microalloying additions. ${ }^{7-14}$ Motivated by recent work on the amorphous $\mathrm{Fe}_{80} \mathrm{P}_{12.5} \mathrm{C}_{7.5}$ system, ${ }^{15}$ which revealed that toughness degraded as GFA improved through alloying additions of $2 \%-5 \%$, we investigate here the effects of microalloying (additions of $1 \%-2 \%$ ) on the toughness of fully amorphous $\mathrm{Cu}_{47} \mathrm{Ti}_{34} \mathrm{Zr}_{11} \mathrm{Ni}_{8}$. The microalloying compositions considered here were $\mathrm{Cu}_{47} \mathrm{Ti}_{33} \mathrm{Zr}_{11} \mathrm{Ni}_{8} \mathrm{Si}_{1}$ (Ref. 7) and $\mathrm{Cu}_{47} \mathrm{Ti}_{33} \mathrm{Zr}_{11} \mathrm{Ni}_{6}$ $\mathrm{Si}_{1} \mathrm{Sn}_{2} .{ }^{8}$ The effect of microalloying on fracture resistance is assessed by measuring the thermodynamic properties, elastic constants, yield strength, hardness, and notch toughness of fully amorphous $3 \mathrm{~mm}$ diameter rods of $\mathrm{Cu}_{47} \mathrm{Ti}_{34} \mathrm{Zr}_{11} \mathrm{Ni}_{8}$, $\mathrm{Cu}_{47} \mathrm{Ti}_{33} \mathrm{Zr}_{11} \mathrm{Ni}_{8} \mathrm{Si}_{1}$, and $\mathrm{Cu}_{47} \mathrm{Ti}_{33} \mathrm{Zr}_{11} \mathrm{Ni}_{6} \mathrm{Si}_{1} \mathrm{Sn}_{2}$.

Ingots of $\mathrm{Cu}_{47} \mathrm{Ti}_{34} \mathrm{Zr}_{11} \mathrm{Ni}_{8}, \mathrm{Cu}_{47} \mathrm{Ti}_{33} \mathrm{Zr}_{11} \mathrm{Ni}_{8} \mathrm{Si}_{1}$, and $\mathrm{Cu}_{47} \mathrm{Ti}_{33} \mathrm{Zr}_{11} \mathrm{Ni}_{6} \mathrm{Si}_{1} \mathrm{Sn}_{2}$ were prepared using appropriate amounts of $\mathrm{Cu}(99.999 \%), \mathrm{Ti}(99.99 \%), \mathrm{Zr}(99.92 \%), \mathrm{Ni}$ (99.995\%), Si (99.9999\%), and Sn (99.99\%). Each ingot was arc melted in a Ti-gettered Argon atmosphere on a watercooled copper hearth and flipped at least four times to ensure chemical homogeneity. For the two alloys containing $\mathrm{Si}$, the $\mathrm{Si}$ was pre-alloyed with $\mathrm{Cu}$ prior to alloying the rest of the

\footnotetext{
${ }^{\text {a) }}$ Author to whom correspondence should be addressed. Electronic mail: grg@caltech.edu.
}

elements. ${ }^{7}$ Rods of $3 \mathrm{~mm}$ diameter and $35 \mathrm{~mm}$ length were cast in a copper mold by injecting from the molten liquid state under a high purity Argon atmosphere using RF induction power for heating. The temperature of the melt prior to injection, monitored with a pyrometer, was $\sim 1150^{\circ} \mathrm{C}$. Rods of $3 \mathrm{~mm}$ in diameter and $30 \mathrm{~mm}$ in length were also produced by suction casting in a copper mold using an Edmund Bühler compact arc melter.

The amorphous structure of the rods was verified by X-ray diffraction (XRD) with a Panalytical X'Pert Pro X-ray diffractometer using $\mathrm{Cu} \mathrm{K}_{\alpha}$ radiation. The XRD scans, which are shown in Fig. 1, display the archetypal amorphous hump. We also performed differential scanning calorimetry (DSC) from room temperature through the end of crystallization using a Netzsch Pegasus 404C DSC at a scanning rate of $0.33^{\circ} \mathrm{C} \mathrm{s}^{-1}$. The DSC scans are shown in Fig. 2, where the arrows denote the glass transition temperature $T_{\mathrm{g}}$ and the crystallization temperature $T_{\mathrm{x}}$. As minorities of $\mathrm{Si}$ and $\mathrm{Sn}$ are substituted into the original composition $\mathrm{Cu}_{47} \mathrm{Ti}_{34} \mathrm{Zr}_{11} \mathrm{Ni}_{8}, T_{\mathrm{g}}$ increases from $408{ }^{\circ} \mathrm{C}$ to $414^{\circ} \mathrm{C}$ to $424{ }^{\circ} \mathrm{C}, T_{\mathrm{x}}$ from $451^{\circ} \mathrm{C}$ to $468{ }^{\circ} \mathrm{C}$ to $487^{\circ} \mathrm{C}$, and $\Delta T$, the difference between $T_{\mathrm{g}}$ and $T_{\mathrm{x}}$, increases from $43{ }^{\circ} \mathrm{C}$ to $54^{\circ} \mathrm{C}$ to $63^{\circ} \mathrm{C}$. $\Delta T$ is a measure of the supercooled liquid stability against crystallization and in certain systems was found to correlate well with glassforming ability.

The elastic constants were calculated from the shear sound speed, longitudinal sound speed, and the density $\rho$. The sound speeds were collected using the pulse-echo overlap technique with $25 \mathrm{MHz}$ piezoelectric transducers, and $\rho$ was measured via the American Society for Testing and Materials (ASTM) C693-93 Archimedes method. The 0.5 kgf HV scale Vickers hardness was measured with a Wilson Instruments 402MVD Microhardness Tester. The compressive yield strength was determined using $3 \mathrm{~mm}$ diameter and $6 \mathrm{~mm}$ tall plane parallel cylinders in an Instron 5500R load frame at a $10^{-3} \mathrm{~s}^{-1}$ strain rate. The values for all measured properties are listed in Table I. As seen in Table I, the increase in $d_{c}$ promoted by minority substitutions of $\mathrm{Si}$ and $\mathrm{Sn}$ is associated with an increase in the density $\rho$, shear modulus $G$, yield strength $\sigma_{\mathrm{y}}$, and Vickers hardness $H V 0.5$.

Cast rods were prepared for notch toughness by cutting a notch through a third of the diameter with a wire saw of 


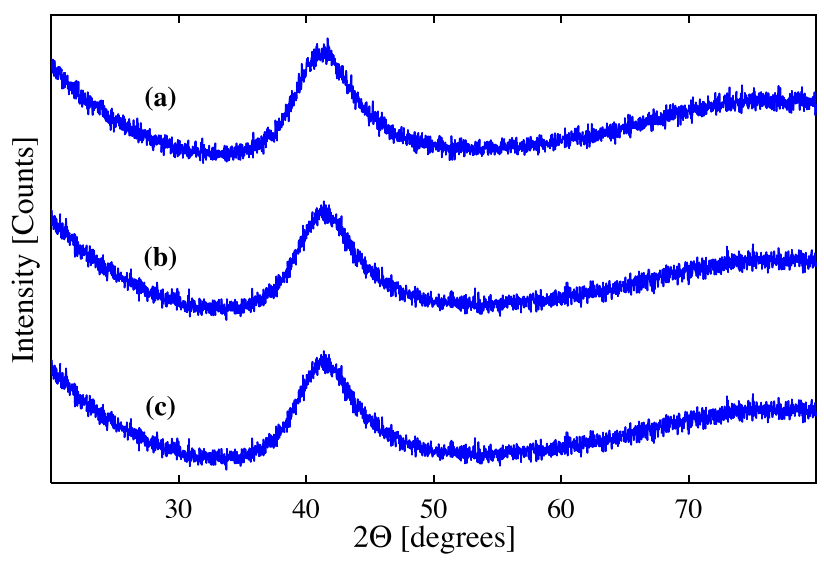

FIG. 1. X-ray diffraction patterns from the cross-sections of $3 \mathrm{~mm}$ diameter rods of (a) $\mathrm{Cu}_{47} \mathrm{Ti}_{34} \mathrm{Zr}_{11} \mathrm{Ni}_{8}$, (b) $\mathrm{Cu}_{47} \mathrm{Ti}_{33} \mathrm{Zr}_{11} \mathrm{Ni}_{8} \mathrm{Si}_{1}$, and (c) $\mathrm{Cu}_{47} \mathrm{Ti}_{33} \mathrm{Zr}_{11}$ $\mathrm{Ni}_{6} \mathrm{Si}_{1} \mathrm{Sn}_{2}$.

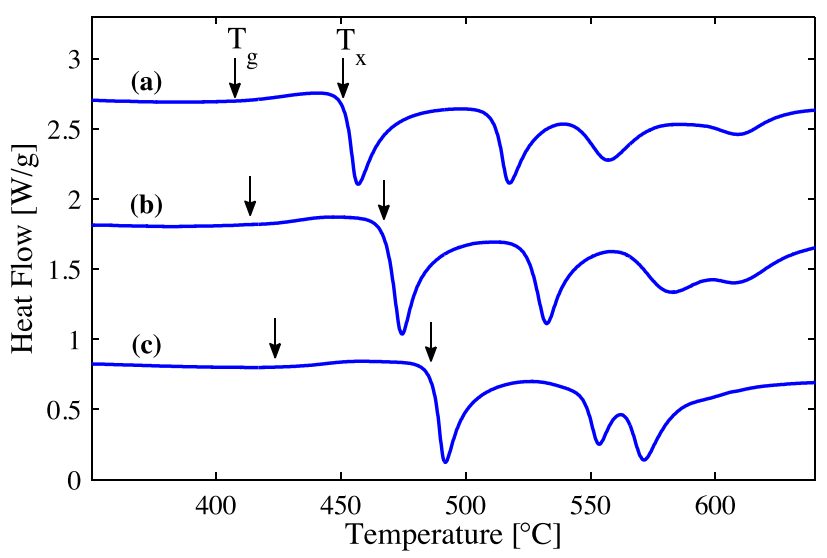

FIG. 2. Differential calorimetry scans at a rate of $20{ }^{\circ} \mathrm{C} \min ^{-1}$ for (a) $\mathrm{Cu}_{47} \mathrm{Ti}_{34} \mathrm{Zr}_{11} \mathrm{Ni}_{8}$, (b) $\mathrm{Cu}_{47} \mathrm{Ti}_{33} \mathrm{Zr}_{11} \mathrm{Ni}_{8} \mathrm{Si}_{1}$, and (c) $\mathrm{Cu}_{47} \mathrm{Ti}_{33} \mathrm{Zr}_{11} \mathrm{Ni}_{6} \mathrm{Si}_{1} \mathrm{Sn}_{2}$. Arrows designate $T_{\mathrm{g}}$ and $T_{\mathrm{x}}$.

$120 \mu \mathrm{m}$ notch root radius. The notched rods were placed in a three-point bending setup with a span distance of $12.7 \mathrm{~mm}$ and loaded at a constant crosshead displacement rate of $0.001 \mathrm{~mm} / \mathrm{s}$. The critical fracture load was recorded and used to calculate the stress intensity factor $K_{\mathrm{Q}}$. The analysis by Murakami for the bending of a cylinder with a straight line notch was employed to accommodate the sample geometry. ${ }^{16}$ At least five and up to nine conditional $K_{\mathrm{Q}}$ measurements were performed for each alloy; the averages and standard deviations are shown in Table I. In contrast to the glass-forming ability, the toughness $K_{\mathrm{Q}}$ decreases as $\mathrm{Si}$ and $\mathrm{Sn}$ are introduced into the alloy. We note that ASTM E399 states that for a linear elastic fracture toughness value to be plane strain $K_{\mathrm{IC}}$, the out-of-plane thickness dimension $B$ must be greater than or equal to $2.5\left(K_{\mathrm{Q}} / \sigma_{\mathrm{y}}\right)^{2} .{ }^{17}$ If this

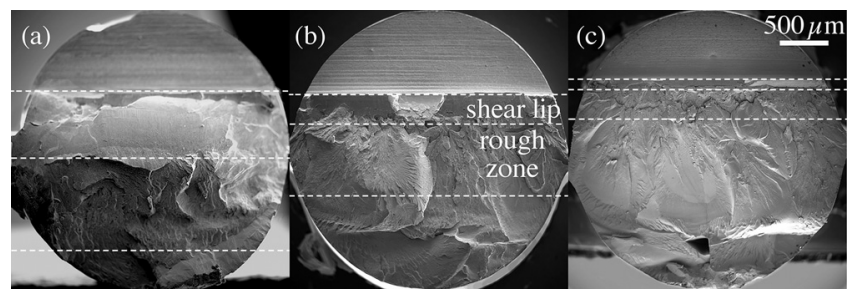

FIG. 3. Scanning electron micrographs of the notch toughness fracture surfaces from $3 \mathrm{~mm}$ diameter rods of (a) $\mathrm{Cu}_{47} \mathrm{Ti}_{34} \mathrm{Zr}_{11} \mathrm{Ni}_{8}$, (b) $\mathrm{Cu}_{47} \mathrm{Ti}_{33} \mathrm{Zr}_{11} \mathrm{Ni}_{8} \mathrm{Si}_{1}$, and (c) $\mathrm{Cu}_{47} \mathrm{Ti}_{33} \mathrm{Zr}_{11} \mathrm{Ni}_{6} \mathrm{Si}_{1} \mathrm{Sn}_{2}$. The four regions associated with fracture are indicated for each specimen.

specimen thickness constraint is not met, the fracture might take place under partial or full plane stress conditions that can result in an overestimation of the fracture toughness. ${ }^{17}$ The effect of plane stress conditions on the measured toughness of metallic glasses was studied in detail by Kawashima et $a l .{ }^{18}$ Due to a relatively high toughness and moderate yield strength of the present alloys, only the more brittle $\mathrm{Cu}_{47} \mathrm{Ti}_{33} \mathrm{Zr}_{11} \mathrm{Ni}_{6} \mathrm{Si}_{1} \mathrm{Sn}_{2}$ alloy meets this plane strain constraint. The sample thickness required for linear elastic plane strain measurements of $\mathrm{Cu}_{47} \mathrm{Ti}_{34} \mathrm{Zr}_{11} \mathrm{Ni}_{8}$ and $\mathrm{Cu}_{47} \mathrm{Ti}_{33} \mathrm{Zr}_{11}$ $\mathrm{Ni}_{8} \mathrm{Si}_{1}$ is $7.4 \mathrm{~mm}$ and $5.4 \mathrm{~mm}$, respectively, both above the critical casting diameter of the alloys, thereby necessitating the use of different measuring techniques. ${ }^{4}$ Nonetheless, the transition to plane stress conditions ongoing from $\mathrm{Cu}_{47} \mathrm{Ti}_{33} \mathrm{Zr}_{11} \mathrm{Ni}_{6} \mathrm{Si}_{1} \mathrm{Sn}_{2}$ to $\mathrm{Cu}_{47} \mathrm{Ti}_{33} \mathrm{Zr}_{11} \mathrm{Ni}_{8} \mathrm{Si}_{1}$ and $\mathrm{Cu}_{47} \mathrm{Ti}_{34}$ $\mathrm{Zr}_{11} \mathrm{Ni}_{8}$ is a direct consequence of increasing alloy toughness, which in essence corroborates the toughness trend between the alloys. The plastic zone radius $r_{\mathrm{p}}$ can be estimated from $r_{\mathrm{p}}=K_{\mathrm{Q}}{ }^{2} / \pi \sigma_{\mathrm{y}}{ }^{2}$, which starts at $940 \mu \mathrm{m}$ for $\mathrm{Cu}_{47} \mathrm{Ti}_{34} \mathrm{Zr}_{11} \mathrm{Ni}_{8}$, decreases to $690 \mu \mathrm{m}$ for $\mathrm{Cu}_{47} \mathrm{Ti}_{33} \mathrm{Zr}_{11}$ $\mathrm{Ni}_{8} \mathrm{Si}_{1}$, and drops to $240 \mu \mathrm{m}$ for $\mathrm{Cu}_{47} \mathrm{Ti}_{33} \mathrm{Zr}_{11} \mathrm{Ni}_{6} \mathrm{Si}_{1} \mathrm{Sn}_{2}$.

Images of the fracture surface were taken with a LEO 1550VP field emission scanning electron microscope. Each fracture surface can be broken down into four regions, listed in the direction of fracture propagation, from the top of the image to the bottom: (1) the notch made by the wire saw, (2) the smooth "shear lip" surface associated with the sliding of the initiating shear band, (3) the jagged "rough zone" associated with the proliferation of plasticity by shear band networking, and (4) the smooth fast-fracture region associated with cavitation and catastrophic crack opening. The length of the notch is required to be between one third and one half of the cylinder diameter; the proportions of the other three zones vary with the alloy's resistance to fracture. The mechanism of toughness in metallic glasses arises from blunting propagating cracks by plastic shear-band sliding at the crack tip and is generally reflected by the roughness of the fracture surface. ${ }^{19}$ As shear bands multiply in number and grow in length from the notch, they produce multiple shear offsets that result in the

TABLE I. The atomic composition, critical rod diameter $d_{\mathrm{c}}{ }^{6-8,13,14}$ glass-transition temperature $T_{\mathrm{g}}$, density $\rho$, yield strength $\sigma_{\mathrm{y}}, 0.5 \mathrm{kgf}$ scale Vickers hardness $H V 0.5$, bulk modulus $B$, shear modulus $G$, Poisson's ratio $\nu$, and notch toughness $K_{\mathrm{Q}}$ for $\mathrm{Cu}_{47} \mathrm{Ti}_{34} \mathrm{Zr}_{11} \mathrm{Ni}_{8}, \mathrm{Cu}_{47} \mathrm{Ti}_{33} \mathrm{Zr}_{11} \mathrm{Ni}_{8} \mathrm{Si}_{1}$, and $\mathrm{Cu}_{47} \mathrm{Ti}_{33} \mathrm{Zr}_{11} \mathrm{Ni}_{6} \mathrm{Si}_{1} \mathrm{Sn}_{2}$.

\begin{tabular}{|c|c|c|c|c|c|c|c|c|c|}
\hline Composition [at. \%] & $d_{\mathrm{c}}[\mathrm{mm}]$ & $T_{\mathrm{g}}\left[{ }^{\circ} \mathrm{C}\right]$ & $\rho\left[\mathrm{g} / \mathrm{cm}^{3}\right]$ & $\sigma_{\mathrm{y}}[\mathrm{GPa}]$ & $H V 0.5\left[\mathrm{kgf} \mathrm{mm}{ }^{2}\right]$ & $B[\mathrm{GPa}]$ & $G[\mathrm{GPa}]$ & $\nu[-]$ & $K_{Q}\left[\mathrm{MPa} \mathrm{m}{ }^{1 / 2}\right]$ \\
\hline $\mathrm{Cu}_{47} \mathrm{Ti}_{34} \mathrm{Zr}_{11} \mathrm{Ni}_{8}$ & 4 & 408 & 6.82 & 1.90 & 581.4 & 126.4 & 37.21 & 0.3660 & $103.4 \pm 8.2$ \\
\hline $\mathrm{Cu}_{47} \mathrm{Ti}_{33} \mathrm{Zr}_{11} \mathrm{Ni}_{8} \mathrm{Si}_{1}$ & 7,4 & 414 & 6.84 & 1.96 & 585.3 & 127.6 & 38.66 & 0.3624 & $90.92 \pm 5.42$ \\
\hline $\mathrm{Cu}_{47} \mathrm{Ti}_{34} \mathrm{Zr}_{11} \mathrm{Ni}_{6} \mathrm{Si}_{1} \mathrm{Sn}_{2}$ & 6 & 424 & 6.87 & 2.00 & 592.2 & 126.1 & 39.39 & 0.3585 & $54.84 \pm 4.67$ \\
\hline
\end{tabular}



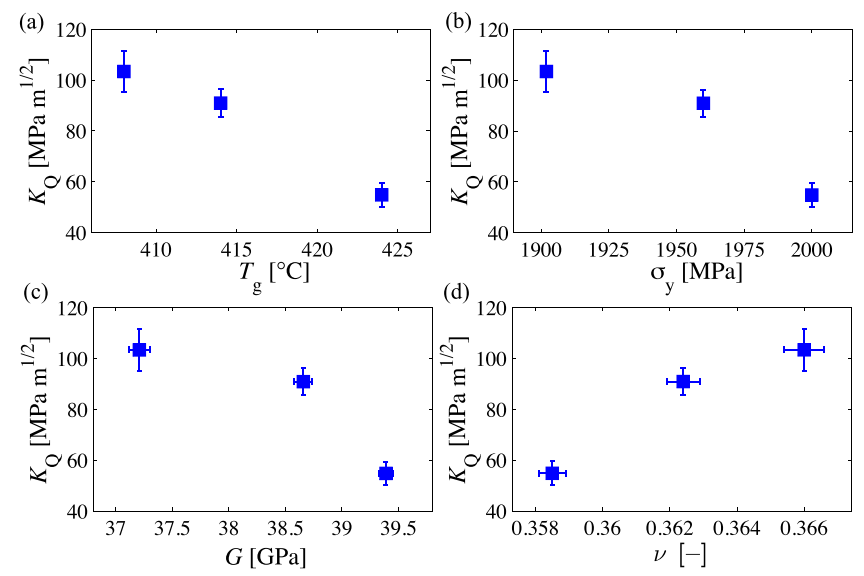

FIG. 4. Notch toughness $K_{\mathrm{Q}}$ vs. (a) glass transition temperature $T_{\mathrm{g}}$, (b) yield strength $\sigma_{\mathrm{y}}$, (c) shear modulus $G$, and (d) Poisson's ratio $\nu$ for $\mathrm{Cu}_{47} \mathrm{Ti}_{34} \mathrm{Zr}_{11} \mathrm{Ni}_{8}, \mathrm{Cu}_{47} \mathrm{Ti}_{33} \mathrm{Zr}_{11} \mathrm{Ni}_{8} \mathrm{Si}_{1}$, and $\mathrm{Cu}_{47} \mathrm{Ti}_{33} \mathrm{Zr}_{11} \mathrm{Ni}_{6} \mathrm{Si}_{1} \mathrm{Sn}_{2}$.

jagged surface of the plasticity regime that follows the initial sliding regime. Once shear bands reach a critical sliding strain, cavitation and crack opening take over, transforming the shear band in to an emerging crack. If the emerging crack cannot be arrested by continued shear banding ahead of the propagating crack tip, as happens in most metallic glasses, catastrophic dimpled fracture is promoted. Thus, the longer the initial shear bands at the notch root and the longer the rough zone, the tougher the glass would be. Comparing the fracture surface of the tougher $\mathrm{Cu}_{47} \mathrm{Ti}_{34} \mathrm{Zr}_{11} \mathrm{Ni}_{8}$ (Fig. 3(a)) with the increasingly less tough $\mathrm{Cu}_{47} \mathrm{Ti}_{33} \mathrm{Zr}_{11} \mathrm{Ni}_{8} \mathrm{Si}_{1}$ (Fig. 3(b)) and $\mathrm{Cu}_{47} \mathrm{Ti}_{33} \mathrm{Zr}_{11}$ $\mathrm{Ni}_{6} \mathrm{Si}_{1} \mathrm{Sn}_{2}$ (Fig. 3(c)), we see that the initial shear offset length decreases, the rough zone length decreases, and the fast fracture zone length increases as toughness decreases.

Inspection of the fracture surfaces suggests that toughness is a result of the interplay between the shear sliding process and the cavitation process. We can investigate this further and correlate the average properties of the glass structure with its toughness to see how microalloying can have such a dramatic influence on toughness. In Fig. 4 we plot the notch toughness $K_{\mathrm{Q}}$ vs. (a) $T_{\mathrm{g}}$, (b) $\sigma_{\mathrm{y}}$, (c) $G$, and (d) $\nu$. The negative correlation of $K_{\mathrm{Q}}$ with $T_{\mathrm{g}}, \sigma_{\mathrm{y}}$, and $G$ agrees with previous studies ${ }^{15}$ and arises from the increase in the barrier height for shear flow. ${ }^{20}$ The positive correlation between $K_{\mathrm{Q}}$ and $\nu$ also agrees with previous studies ${ }^{21}$ and is explained by how $\nu$ quantitatively describes the ratio of the cavitation barrier to the shear flow barrier. From Table I, as Si and Sn are substituted in, the shear modulus is raised by just $2 \%-4 \%$ with each substitution, while the bulk modulus remains roughly constant, resulting in a slight but meaningful drop in $\nu$. These seemingly minor shifts in the elastic constants are indicative of significant structural rearrangements in the atomic structure of the glass that dramatically influence the fracture resistance.
Microalloying in the present work, as well as somewhat larger alloying additions in previous work, ${ }^{15}$ is shown to sharply decrease toughness by slightly increasing the shear flow barrier, reflected in the negative correlation between toughness and shear modulus, glass-transition temperature, and yield strength (and the positive correlation with Poisson's ratio). However, as shown in another recent study, ${ }^{5}$ microalloying can improve glass-forming ability while also dramatically improving toughness. This has been accomplished by increasing the barrier for shear flow while also increasing the cavitation barrier even further, resulting in an overall larger shear sliding capacity prior to fracture. One may therefore conclude that microalloying is a powerful instrument that can strongly and positively influence not only the glass forming ability but also the toughness of metallic glasses. Hence, understanding and controlling microalloying, as attempted in this work, would be key in optimizing the design of future metallic glass alloys.

Authors would like to acknowledge the Caltech MURF program for undergraduate support.

${ }^{1}$ Z. Lu and C. Liu, J. Mater. Sci. 39, 3965 (2004).

${ }^{2}$ W. H. Wang, Prog. Mater. Sci. 52, 540 (2007).

${ }^{3}$ M. D. Demetriou, M. Floyd, C. Crewdson, J. P. Schramm, G. Garrett, and W. L. Johnson, Scr. Mater. 65, 799 (2011).

${ }^{4}$ M. D. Demetriou, M. E. Launey, G. Garrett, J. P. Schramm, D. C. Hofmann, W. L. Johnson, and R. O. Ritchie, Nat. Mater. 10, 123 (2011).

${ }^{5}$ S. M. Chathoth, B. Damaschke, J. P. Embs, and K. Samwer, Appl. Phys. Lett. 95, 191907 (2009).

${ }^{6}$ X. Lin and W. Johnson, J. Appl. Phys. 78, 6514 (1995).

${ }^{7}$ H. Choi-Yim, R. Busch, and W. Johnson, J. Appl. Phys. 83, 7993 (1998).

${ }^{8}$ E. Park, H. Lim, W. Kim, and D. Kim, J. Non-Cryst. Solids 298, 15 (2002).

${ }^{9}$ E. Park, D. Kim, T. Ohkubo, and K. Hono, J. Non-Cryst. Solids 351, 1232 (2005).

${ }^{10}$ M. Calin and J. Eckert, Adv. Eng. Mater. 7, 960 (2005).

${ }^{11}$ M. Calin, M. Stoica, J. Eckert, A. R. Yavari, and L. Schultz, Mater. Sci. Eng. A 392, 169 (2005).

${ }^{12}$ E. S. Park, H. J. Chang, J. S. Kyeong, and D. H. Kim, J. Mater. Res. 23, 1995 (2008).

${ }^{13}$ E. S. Park, H. J. Chang, and D. H. Kim, J. Alloys Compd. 504(Suppl. 1), S27 (2010).

${ }^{14}$ S. Venkataraman, M. Stoica, S. Scudino, T. Gemming, C. Mickel, U. Kunz, K. B. Kim, L. Schultz, and J. Eckert, Scr. Mater. 54, 835 (2006).

${ }^{15}$ M. D. Demetriou, G. Kaltenboeck, J.-Y. Suh, G. Garrett, M. Floyd, C. Crewdson, D. C. Hofmann, H. Kozachkov, A. Wiest, J. P. Schramm, and W. L. Johnson, Appl. Phys. Lett. 95, 041907 (2009).

${ }^{16}$ Y. Murakami, Stress Intensity Factors Handbook, 1st ed. (Pergamon, Oxford, UK, 1987).

${ }^{17}$ E08 Committee, Test Method for Linear-Elastic Plane-Strain Fracture Toughness KIc of Metallic Materials, 2010th ed. (ASTM International, West Conshohocken, PA, 2009).

${ }^{18}$ A. Kawashima, H. Kurishita, H. Kimura, and T. Zhang, Mater. Trans. 46, 1725 (2005).

${ }^{19}$ J.-Y. Suh, R. D. Conner, C. P. Kim, M. D. Demetriou, and W. L. Johnson, J. Mater. Res. 25, 982 (2010).

${ }^{20}$ W. L. Johnson, M. D. Demetriou, J. S. Harmon, M. L. Lind, and K. Samwer, MRS Bull. 32, 644 (2007).

${ }^{21}$ J. J. Lewandowski, W. H. Wang, and A. L. Greer, Philos. Mag. Lett. 85, 77 (2005). 